\title{
MCA (Information Science and Management): The Next Generation Interdisciplinary specialization for Social, Business, Health \& Mathematical Sciences-A Step for promoting Digital Humanities
}

\author{
P.K. Paul ${ }^{*}$, P.S. Aithal ${ }^{2}$, A. Bhuimali ${ }^{3}$ \\ ${ }^{1 *}$ DCIS, Raiganj University, West Bengal, India \\ ${ }^{2}$ Vice Chancellor, Srinivas University, Karnataka, India \\ ${ }^{3}$ Vice Chancellor, Raiganj University, Raiganj, West Bengal, India \\ *Corresponding Author: pkpaul.infotech@gmail.com
}

Available online at: www.isroset.org

Received $20^{\text {th }}$ Aug 2017, Revised $09^{\text {th }}$ Sep 2017, Accepted $15^{\text {th }}$ Oct 2017 , Online $30^{\text {th }}$ Oct 2017

\begin{abstract}
Information Science is an important domain for building healthy information infrastructure for almost all kind of organization and institutions for almost all kind of organization and institutions and sector. Information and its growing number is the main reason behind the requirement of information and similar domain. Information Science is actually an interdisciplinary domain combines with so many subjects related to information and processing of data and similar facet. Computer is one of the important gradients in Information Science for healthy and sophisticated information system designing and development. In the education sector, there are so many courses available which are related to computers such as Computer Science, Computer Application, Computer Science and Engineering, IT and so on and comes with so many nomenclatures and levels. Information Science is also a computer related subject but having information concentration. MCA is one of the important and popular courses in computing applications in India; which deals with IT applications in the industrial and society problems. This paper talks about MCA in respect of possibilities of Information Science specialization in such programme for better information infrastructure development. Several contents of this paper are directly included in the thesis of the author (for obtaining research degree) and the fact is hereby acknowledged. Paper deals with many aspects of Information Science including its need and characteristics, educational situation in India and globally in brief manner and way to introduce this proposal in contemporary Indian MCA programme.
\end{abstract}

Keywords - Information, Information Science, IST, Knowledge, Social Development, Digital Divide, Information Literacy, Information Divide, Information Development, Academics, Information Systems

\section{INTRODUCTION}

Information Science is an interdisciplinary Science of Sciences; it is one of the important domains which is responsible for so many information activities such as collection, selection, organization, processing, management and dissemination. Information Science is responsible for information infrastructure building which including conventional workplace of Information Science i.e. Information Foundation and related organizations, public information systems, Medical Information Systems, Chemical and Bio-Information infrastructure buildings and so on (See Fig:2 for more details). [10, 15]. Though for development of such activities building Information Science education is very much important in India. Still, Information Science programme is offered in very minimum institutions and only around 10 institutions [10, 13]. However, MCA course is offered in more than 2,400 Computer Application colleges and Engineering educational institutions. There are provisions and possibilities in which Information Science aspects may include in BCA/MCA Programmes. Ultimately such initiative will be helpful for Information Systems development which will be powered by modern and up to date Information Technology and Computing Systems [16, 18].

\section{OBJECTIVE}

This paper deals with so many aim and objective; which including but not limited to:-

- To know basic about Information Science and its basic characteristics and features.

- To learn about the main component and field of Information Science and allied domain.

- To know about Information Science and relationship and integration with computing and allied domain. 
- To get a brief overview on Information Science and the institutions offering educational programmes in India.

- To prepare a model and proposed curriculum of MCA with focus or specialization in Information Science.

- To find out main challenges and issues in relation to MCA [Information Science] programme.

\section{INFORMATION SCIENCE: BASICS}

Information Science is a broad field and combination of so many domains such as Information Technology, Computer Science, Information Studies, Knowledge Management, Management Science, and Mathematical Science and so on (See Fig: 1 for more details). Information Science is a domain which is responsible for information system and infrastructure building with the help of manual tools, and computational tools [22].

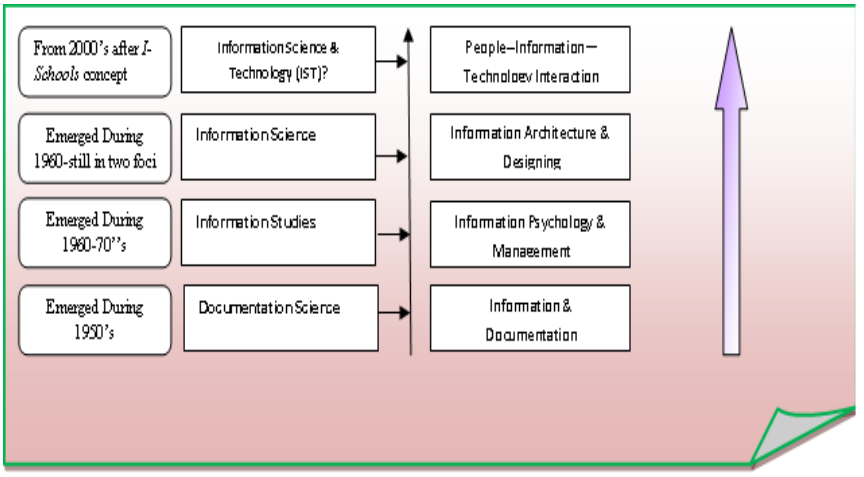

Fig: 1-Generation wise Information Field changes and changing nomenclature at a glance

Initially, Information Science originated from the information field and due to the advancement of technologies comes as an advanced field of Applied Science with the aim of information and side by side technological solution. Information Science is an important domain in today's age as information is needed in almost all the organizations, and institutions. Information Science curriculum in today's courses included in such a manner in which computational aspects and fundamentals related to information and society are molded nicely [23].

\section{COMPUTER APPLICATION AND MCA DEGREE}

Computer Application is one of the important domain and nomenclature in Indian academics. Computer Application mainly deals with computer related application and utilization.

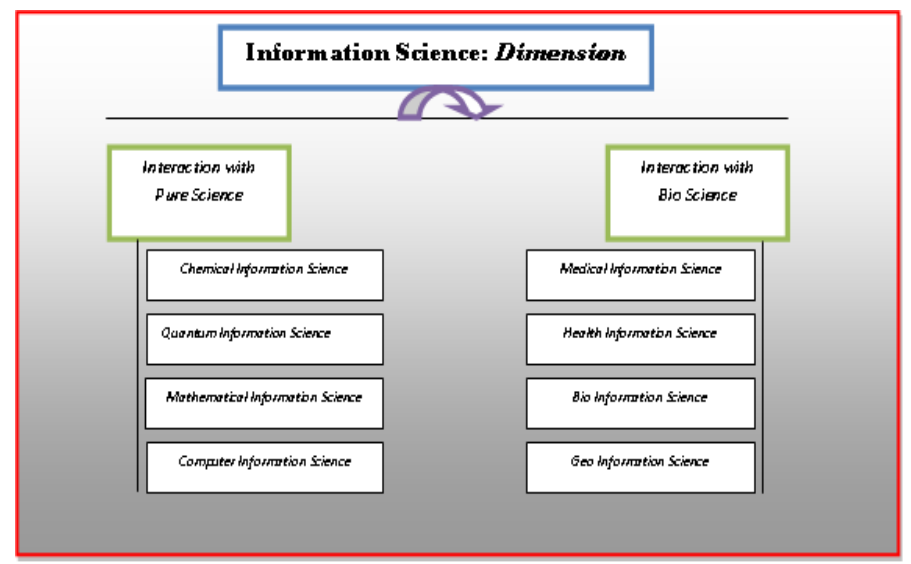

Fig: 2-Depicted Types of Information Science in respect to Domain focus

This programme mainly focuses on Application and packages rather than the development of new hardware systems, tools, and embedded systems [12, 19]. The flagship programme of Computer Application nomenclature is BCA/MCA while out of these two; MCA is most important and valuable.

The proposed MCA Programme is depicted of 3 year duration and within semester approach. The students entering MCA must have completed a Bachelor Degree such as BCA/BSc/BCom/BA degree with Mathematics/ Computer Science as one of the subjects at $10+2$ level or graduation. The MCA programme is deemed as equivalent to Engineering degree of computing i.e. BE/BTech-Information Technology/ Computer Science and Engineering programme. The regularity body of MCA is All India Council for Technical Education [AICTE] as far as India is concerned. It is important to note that a proposed and model curriculum is already presented by AICTE and provided with total 25 theoretical papers and 10 as laboratory practice papers. The basic features of the curriculum are as follows-

According to AICTE guidelines, the core papers of IT for the MCA degree is listed as follows-

1. Introduction to Information Technology

2. Computer Organization and Architecture

3. Programming and Data Structures

4. Information Systems. Analysis, Design, and Implementation

5. Operating Systems

6. Data Base Management Systems

7. Computer Communication Networks

8. Object-oriented Analysis and Design

9. Network Programming

10. Software Engineering I

11. Software Engineering II 
12. Artificial Intelligence and Applications

However, here total 12 papers had been proposed by the AICTE for MCA course as non-computer science core papers. Out of which 6 papers have deals with Management and 4 are as elective. The list of such specializations have depicted and mentioned in the Table: 1 and here out of six semesters, the last semester (VI Semester) a project work has been proposed.

\begin{tabular}{|l|l|}
\hline $\begin{array}{c}\text { Core Management Papers } \\
\text { [5 Papers] }\end{array}$ & \multicolumn{1}{|c|}{$\begin{array}{c}\text { Elective Management } \\
\text { Papers [Any 4 Paper] }\end{array}$} \\
\hline & 1. Managerial Economics \\
1. Introduction of & 2. Corporate Planning \\
Management Functions & 3. Foundations of Decision \\
2. Oral and Written & Processes \\
Communication & 4. Investment Technology \\
3. Accounting and & 5. Business Finance \\
Management Control & 6. Taxation Practices \\
4. Management Support & 7. MIS Framework and \\
Systems & Implementation \\
5. Organizational Behavior & 8. Management of Software \\
& Projects \\
\hline
\end{tabular}

Table 1 : List of non-computer science core papers.

\section{INFORMATION SCIENCE AND COMPUTER APPLICATION INTEGRATION}

Already discussed that Information Science is a domain of interdisciplinary nature and combines with several domains of science, engineering, technology, management as well as humanities (social science gradients) which are related with the information processing and management directly or indirectly $[12,18]$. The IS and its increasing association in the practicing field and domain created a new nomenclature called 'Information Science and Technology'. Importantly, Information Science combines and related with following aspects and facets-

In Engineering- Computer Engineering, Mechanical Engineering, Electronics and Communication Engineering, Telecommunication

In Science- Bio-Science, Physics, Chemistry, Mathematics, Cognitive Science

In Humanities-Social Science, Library Science,

Documentation

\begin{tabular}{|c|c|c|c|c|c|c|c|}
\hline Semester & \multicolumn{7}{|c|}{ Papers } \\
\hline $\begin{array}{c}\text { Semester } \\
-1\end{array}$ & $\begin{array}{l}\text { Introduction of } \\
\text { IT }\end{array}$ & $\begin{array}{c}\text { Computer } \\
\text { Organization } \\
\text { and Architecture }\end{array}$ & $\begin{array}{l}\text { Programming } \\
\text { and Data } \\
\text { Structure }\end{array}$ & $\begin{array}{l}\text { Introduction to } \\
\text { Management } \\
\text { Function }\end{array}$ & $\begin{array}{l}\text { Mathematical } \\
\text { Foundations }\end{array}$ & IT Lab & $\begin{array}{c}\text { Programming } \\
\text { Lab }\end{array}$ \\
\hline $\begin{array}{l}\text { Semester- } \\
3\end{array}$ & $\begin{array}{l}\text { Database } \\
\text { Management } \\
\text { Systems }\end{array}$ & $\begin{array}{c}\text { Computer } \\
\text { Communication } \\
\text { and Networks }\end{array}$ & $\begin{array}{l}\text { Object Oriented } \\
\text { Analysis and } \\
\text { Design }\end{array}$ & $\begin{array}{l}\text { Management } \\
\text { Support } \\
\text { System }\end{array}$ & $\begin{array}{l}\text { Statistical } \\
\text { Computing }\end{array}$ & DBMS Lab & $\begin{array}{l}\text { Statistical } \\
\text { Lab }\end{array}$ \\
\hline Semester- & Networking & Software & Elective-1 & Organizational & Elective-2 & Network Lab & CASE Tools \\
\hline
\end{tabular}

In Management Science- Administration and Leadership, Management Science.

The MCA curriculum designed and prepared by the All India Board of Computer Science, Engineering/ Technology and Applications (AIBCSA), which was set up by AICTE, New Delhi. It is important to note that the core of Information Science is positively possible to introduce in the MCA programme. It is a fact that the MCA curriculum already having components of computing/ IT/ Mathematics and Business and Management and thus by the inclusion of few information fundamentals and humanities gradients it is achievable to build Information Science/IST focused MCA programme. Here, in the proposed MCA, we have to include some important gradients of Information Science in such a way that a proper general balancing can be made without ignoring the computing gradients. Here three approaches have been proposed, in the first approach [which is listed in Table: 2] the MCA common papers kept as same provided by the committee of AICTE. Here just a few more papers have added related with the Information Science in Elective papers of MCA outline.

However, in second approach (i.e. here listed in Table: 3) the Information Science main/core gradients have included and distributed from the beginning of the programme and all the semesters have deals with AICTE's main gradients as well as the fundamentals of the Information Studies, Information and Knowledge Management including the Social Science gradients. Hence, the MCA programme looks like Information Science nature supported by the computing programme $[05,09,12]$.

While in the third approach, which is listed in Table: 4 we have proposed and depicted the same papers, as well as, outline of the main course (as MCA committee recommended) but here many gradients and specialized Information Science as elective programme have provided from the fifth (V) semester which is listed in fig. Figure$4 / A / B / C$. The electives have proposed with the following flavors such as-

- Medical Information Science.

- Geo Information Science.

- Chemical Information

Science. 


\begin{tabular}{|c|c|c|c|c|c|c|c|c|}
\hline 4 & Programming & Engineering-I & $\begin{array}{l}\text { Information } \\
\text { Science and } \\
\text { Services }\end{array}$ & Behavior & $\begin{array}{l}\text { Knowledge } \\
\text { Organization- } \\
\text { Theory and } \\
\text { Practice }\end{array}$ & & Lab & \\
\hline $\begin{array}{l}\text { Semester- } \\
5\end{array}$ & $\begin{array}{c}\text { AI and } \\
\text { Applications }\end{array}$ & $\begin{array}{c}\text { Software } \\
\text { Engineering-II }\end{array}$ & $\begin{array}{l}\text { Elective-3 } \\
\text { Digital } \\
\text { Information } \\
\text { Systems, and } \\
\text { Knowledge } \\
\text { Economy }\end{array}$ & $\begin{array}{c}\text { Elective-4 } \\
\text { Knowledge } \\
\text { Organization-II }\end{array}$ & $\begin{array}{l}\text { Optimization } \\
\text { Technique }\end{array}$ & $\begin{array}{c}\text { AI and } \\
\text { Application } \\
\text { Lab }\end{array}$ & $\begin{array}{c}\text { Optimization } \\
\text { Technique } \\
\text { Lab }\end{array}$ & $\begin{array}{c}\text { Industrial } \\
\text { Lecture, } \\
\text { Seminar, } \\
\text { small } \\
\text { project }\end{array}$ \\
\hline $\begin{array}{l}\text { Semester- } \\
6\end{array}$ & $\begin{array}{l}\text { Project and } \\
\text { seminar }\end{array}$ & $\begin{array}{l}\text { Project and } \\
\text { seminar }\end{array}$ & $\begin{array}{l}\text { Project and } \\
\text { seminar }\end{array}$ & $\begin{array}{l}\text { Project and } \\
\text { seminar }\end{array}$ & $\begin{array}{l}\text { Project and } \\
\text { seminar }\end{array}$ & $\begin{array}{l}\text { Project and } \\
\text { seminar }\end{array}$ & $\begin{array}{l}\text { Project and } \\
\text { seminar }\end{array}$ & Seminar \\
\hline
\end{tabular}

Table: 2 MCA papers same as provided by the committee of AICTE but few IS/IST papers have added.

\begin{tabular}{|c|c|c|c|c|c|c|c|c|}
\hline Semester & \multicolumn{8}{|c|}{ Papers } \\
\hline $\begin{array}{c}\text { Semester } \\
-2\end{array}$ & $\begin{array}{l}\text { Information } \\
\text { System Analysis } \\
\text { Design and } \\
\text { Implementation }\end{array}$ & $\begin{array}{l}\text { Operating } \\
\text { Systems }\end{array}$ & $\begin{array}{c}\text { Oral and } \\
\text { Wireless } \\
\text { Communication } \\
\text { and Information } \\
\text { Networks }\end{array}$ & $\begin{array}{c}\text { Information } \\
\text { Systems-Trendz }\end{array}$ & $\begin{array}{l}\text { Knowledge } \\
\text { Management } \\
\text { and } \\
\text { Multimedia } \\
\text { System }\end{array}$ & $\begin{array}{c}\text { Business } \\
\text { Programming } \\
\text { Lab }\end{array}$ & $\begin{array}{l}\text { Linux and } \\
\text { Windows }\end{array}$ & \\
\hline $\begin{array}{l}\text { Semester- } \\
4\end{array}$ & DBMS-2 & $\begin{array}{c}\text { Intelligent } \\
\text { Information } \\
\text { Systems and UE }\end{array}$ & CISCO Systems & $\begin{array}{c}\text { Organizational } \\
\text { Behavior }\end{array}$ & Virtual Lan & Network Lab & $\begin{array}{l}\text { CASE Tools } \\
\text { Lab }\end{array}$ & \\
\hline $\begin{array}{l}\text { Semester- } \\
5\end{array}$ & $\begin{array}{c}\mathrm{AI} \text { and } \\
\text { Applications }\end{array}$ & $\begin{array}{c}\text { Software } \\
\text { Engineering-II }\end{array}$ & $\begin{array}{l}\text { Computing for } \\
\text { People }\end{array}$ & IT For DSS & $\begin{array}{l}\text { Optimization } \\
\text { Technique }\end{array}$ & $\begin{array}{c}\text { AI and } \\
\text { Application } \\
\text { Lab }\end{array}$ & KO-Lab-2 & $\begin{array}{c}\text { Industrial } \\
\text { Lecture, } \\
\text { Seminar, } \\
\text { small } \\
\text { project }\end{array}$ \\
\hline
\end{tabular}

Table: 3 The IS/IST papers have added from the beginning of the semesters.

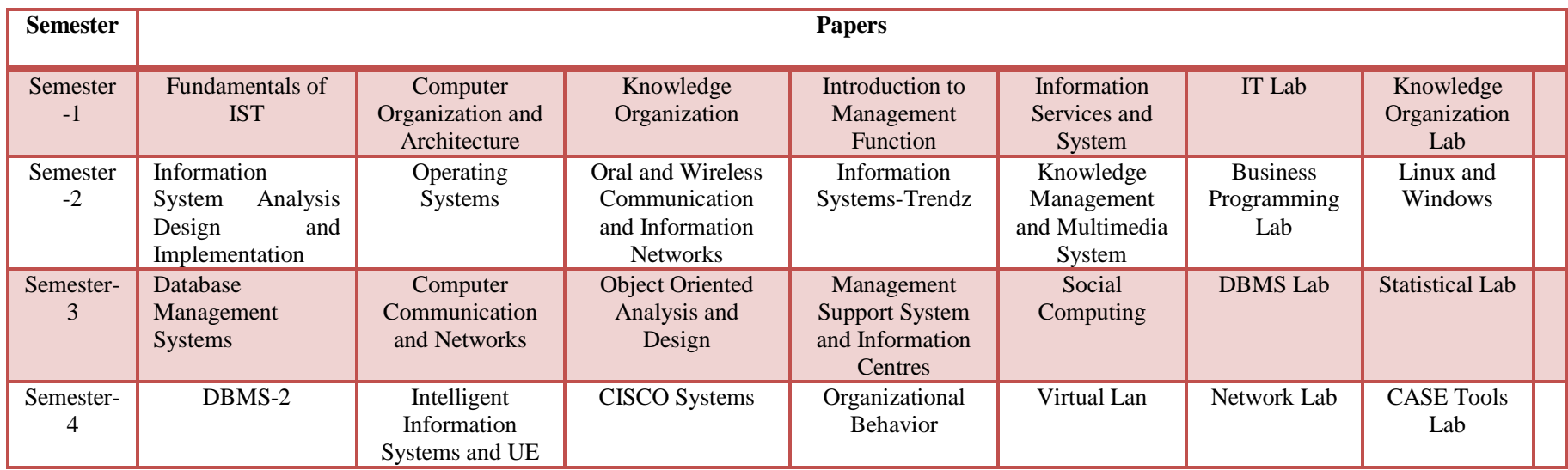

Table: 4- Model approach where up to fourth semester the core MCA papers and IST papers have proposed with possibilities of domain based specialization at fifth and sixth semester.

\begin{tabular}{|c|c|c|c|c|c|c|c|}
\hline Semester & \multicolumn{5}{|c|}{ Papers } \\
\hline $\begin{array}{c}\text { Semester -5 } \\
\text { Specialization }\end{array}$ & Human Anatomy & Health Policies & Health IT and DSS & $\begin{array}{c}\text { Health } \\
\text { Informatics } \\
\text { Software-1 }\end{array}$ & $\begin{array}{c}\text { Medical 2.0 and Web } \\
\text { Designing }\end{array}$ & $\begin{array}{c}\text { Health } \\
\text { Informatics } \\
\text { Software-1-Lab }\end{array}$ & \\
\hline
\end{tabular}




\begin{tabular}{|c|c|c|c|c|c|c|}
\hline $\begin{array}{l}\text { Semester -6 } \\
\text { Specialization }\end{array}$ & $\begin{array}{l}\text { Telemedicine and } \\
\text { Network } \\
\text { designing }\end{array}$ & $\begin{array}{c}\text { Health } \\
\text { Informatics } \\
\text { Software-2 }\end{array}$ & $\begin{array}{c}\text { Knowledge } \\
\text { Organization for } \\
\text { Medical Literature }\end{array}$ & $\begin{array}{c}\text { Medical } \\
\text { Tourism and } \\
\text { Computers }\end{array}$ & $\begin{array}{c}\text { Knowledge } \\
\text { Organization for } \\
\text { Medical Literature- } \\
\text { Practice }\end{array}$ & $\begin{array}{c}\text { Health } \\
\text { Informatics } \\
\text { Software-2-Lab }\end{array}$ \\
\hline
\end{tabular}

Table: 4/A- Specialization-1 of MCA with Medical Information Science

\begin{tabular}{|c|c|c|c|c|c|c|}
\hline Semester & \multicolumn{6}{|c|}{ Papers } \\
\hline $\begin{array}{l}\text { Semester -5 } \\
\text { Specialization }\end{array}$ & $\begin{array}{l}\text { Chemical } \\
\text { Informatics- } \\
\text { Basics }\end{array}$ & $\begin{array}{l}\text { Chemical } \\
\text { Informatics } \\
\text { Application }\end{array}$ & $\begin{array}{c}\text { Chemo Informatics } \\
\text { Software-Theory and } \\
\text { Practice }\end{array}$ & Biology and IT & $\begin{array}{l}\text { Systems and } \\
\text { Computers }\end{array}$ & $\begin{array}{l}\text { Textile Science } \\
\text { and Informatics }\end{array}$ \\
\hline $\begin{array}{l}\text { Semester -6 } \\
\text { Specialization }\end{array}$ & $\begin{array}{l}\text { MIS in } \\
\text { Chemical Lab }\end{array}$ & $\begin{array}{c}\text { Chemical } \\
\text { Compounding }\end{array}$ & $\begin{array}{l}\text { KM for Chemical } \\
\text { Documents }\end{array}$ & $\begin{array}{l}\text { Pharmaceutics and } \\
\text { Chemo informatics }\end{array}$ & $\begin{array}{l}\text { KM for Chemical } \\
\text { Documents- } \\
\text { Practice }\end{array}$ & $\begin{array}{c}\text { MIS in } \\
\text { Chemical Lab- } \\
\text { Practical }\end{array}$ \\
\hline
\end{tabular}

Table: 4/B-Specialization-2 of MCA with Geo Information Science

\begin{tabular}{|c|c|c|c|c|c|c|}
\hline Semester & & & & Paper: & & \\
\hline $\begin{array}{l}\text { Semester -5 } \\
\text { Specialization }\end{array}$ & $\begin{array}{l}\text { Geo IS- } \\
\text { Basics }\end{array}$ & GIS-Practice-1 & GPRS and GPS & $\begin{array}{l}\text { Topography } \\
\text { and IT }\end{array}$ & $\begin{array}{c}\text { Topographical and Geo } \\
\text { Documentation }\end{array}$ & GIS-Practice-2 \\
\hline $\begin{array}{l}\text { Semester -6 } \\
\text { Specialization }\end{array}$ & $\begin{array}{l}\text { Space and } \\
\text { IT }\end{array}$ & $\begin{array}{c}\text { Oceanography and } \\
\text { GIS }\end{array}$ & $\begin{array}{l}\text { 3D Modeling } \\
\text { and GIS }\end{array}$ & $\begin{array}{c}\text { Image } \\
\text { Processing }\end{array}$ & Multimedia GIS & $\begin{array}{c}\text { Cartographic } \\
\text { technique and IT }\end{array}$ \\
\hline
\end{tabular}

Table: 4/C-Specialization-3 of MCA with Chemo Information Science

Thus it is worthy to note that the proposed $3^{\text {rd }}$ approach not only able and competent to produce skill of computing based information infrastructure system building as well as able to manage the growing need of sector wise (i.e. discipline wise) information and technologies. Thus, one degree holders shall be able in Health Information System, Geo Information System and classical information management which are in high demand in a contemporary context.

\section{Challenges and Issues for Proposed MCA [INFORMATION SCIENCE]}

Building MCA [Information Science] may come with so many possibilities and opportunities but it comes with so many challenges and issues; some of them are as follows-

- MCA [Information Science] needs the core of existing paper and subject prepared by AICTE committee.

- Training of such programme, interdisciplinary teachers are needed as they need to know IT and Computing to Information fundamentals for computational and manual Information System building

- Running such courses needs authorized permission of concerned authorities, body, and association.
- Government support and educational initiative is still a less important issue which is so essential to take care.

- Information Science is an interdisciplinary field and which is needed for Information System building in Information Foundation such as Information Centre, Documentation Centre, Libraries and organizational Information System building and hence Information Science is needed and during preparation of MCAInformation Science it is essential to take care the matter of manual knowledge organization and some aspects such as Information and Communication, Information Society, Information Management, Economic aspects of Information and similar facet inclusion in the perspective proposed programmes.

- Still, Information Science programmes are very much limited in India; only around 10 institutes are offers flagship programme of MSc- Information Science which listed in Table: 5 and hence if fullfledged programme is not possible to introduce in Information Science then it may be offered as MCA [Information Science].

\section{SugGeSTION}

- Information Foundations, Association and Computing and IT Association need to collaborate each other for building healthy Information Infrastructure with sophisticated IT support; 
- AICTE, Ministry of IT, Education and similar departments are need to take proper initiative to start MCA- Information Science programme;

- During preparation of the programme, it is very much essential that the balancing of Information Fundamentals should be kept in mind;

- Apart from MCA programme such specialization may also be started in MCA- Information Science for producing skilled IT based Information Professionals;

- Initially if During MCA department wants to introduce MCA- Information Science specialization then appointing Adjunct Professor with Information Fundamentals specialization will be a better alternative.

\section{CONCLUSION}

Information Science is one of the important and valuable domain as sophisticated Information Management backed by the Computing is possible with this domain. India is one of the largest educational hub in the world with near about 30000 higher educational institutions but still, the development of Information Science and the related domain is in very much limited in India [12, 19]. Hence, a better alternative may be introducing Information Science specialization at $\mathrm{BCA} / \mathrm{BCA}$ or $\mathrm{BSc} / \mathrm{MSc}-\mathrm{IT}$ level. Proper planning, integration of computing and information related departments; associations may be an important alternative to manage Information explosion and future Information Solution.

\section{REFERENCES}

[1] Cohen, E. B. (2004). Applying the Informing Science Framework to Higher Education: Knowledge Development, Management, and Dissemination. Konferencja Pozyskiwanie wiedzy i zarządzanie wiedzą (Proceedings of the Knowledge Acquisition and Management Conference) May 13-15, 2004 Kule, Poland.

[2] Cohen, Eli B. and Nycz Malgorzata (2006). Learning Objects and ELearning: an Informing Science Perspective. Interdisciplinary Journal of Knowledge and Learning Objects Volume 2, 2006.

[3] Martin, S.B. (1998). Information technology, employment, and the information sector: Trends in information employment 1970-1995. Journal of the American Society for Information Science, 49(12), 1053-1069.

[4] Michael Buckland and Ziming liu (1995).History of information science. Annual Review of Information Science and Technology vol. 30: 385-416.

[5] Paul, P. K. (2012). Information Scientist: Roles and Values with special Reference to their Appropriate Academic Programme and its availability in India:" International Journal of Information Dissemination and Technology, Vol. 2, No. 4, October-December-2012, Page-245-248, ISSN-2229-5984

[6] Paul, P. K., D Chaterjee,R Bhatnagar, Uma Pricilda (2012). Information Scientist: Contemporary innovative techno management roles with special reference to Information Scientist Vs Information Technologist: A Study", Indian Journal of Information Science and Applications [IJISA], Vol. 2. No. 1, Jan-Jun-2012, Academic Research Publication, New Delhi, Page-47-50, ISSN-2249-3689.

[7] Paul, P.K., R Rajesh, D Chatterjee, M K Ghose (2013). Information Scientist: Technological and Managerial Skill requirement in $21^{\mathrm{st}}$ century" in 'Information Studies' Vol. 19, No. 1, RCIS,Chennai, Page29-36, ISSN-0971-6726.

[8] Paul, P. K., (2013). MSc-Information Science [Geo Informatics]: Overview emphasizing twoproposed curriculum for sophisticated Geo Spatial development. International Journal of Pharmaceutical and Biological Research (IJPBR), Vol 4 Issue 5, ISSN : 0976- 285X, Vol218-227.

[9] Paul, P. K., (2013). Environment and Sustainable Development with Cloud Based Green Computing:A Case Study" Scholars Academic Journal of Biosciences (SAJB), 1(6):337-341 ISSN 2321-6883.

[10] Paul, Prantosh Kumar, (2013). Nutrition Information Networks: Possible domain and Future Potentials. Scholars Academic Journal of Biosciences (SAJB), 1(6):342-345, ISSN 2321-6883.

[11] Paul, P.K., K L Dangwal (2014). Cloud Computing Based Educational Systems and iits challenges and opportunities and issues" Turkish Online Journal of Distance Education-TOJDE, ISSN 1302-6488 Volume: 15 Number: 1, Page-89-98.

[12] Paul, P.K., K L Dangwal, B Karn, (2013). Engineering Academics, Departments and Community : Emphasizing Some Educational Perspective of Information Science [IS], EDUCATIONAL QUEST: An International Journal of Education and Applied Social Sciences, 4(2), 141-146.

[13] Paul, P.K., K L Dangwal, A Kumar (2013). Information Infrastructure and Academic and Education World: The Role and Opportunities in Contemporary Perspective. International Journal of Education for Peace and Development: Vol. 1 No. 1, Page-31-36.

[14] Reichman, F. (1961). Notched Cards. In R. Shaw (Ed.), The state of the library art04(01), pp. 11-55). New Brunswick, NJ: Rutgers, The State University, Graduate School of Library Service.

[15] Saracevic, T. (1996). Relevance reconsidered. Information science: Integration in perspectives. In Proceedings of the Second Conference on Conceptions of Library and Information Science (pp. 201-218), Copenhagen, Denmark: Royal School of Library and Information Science.

[16] Saracevic, T. (1975). Relevance: A review of and a framework for the thinking on the notion in information science. Journal of the American Society of Information Science, 26(6), 321-343.

[17] Saracevic, T. (1979a). An essay on the past and future of information science education. I. Historical overview. Information Processing \&Management, 15(1), 1-15.

[18] Saracevic, T. (1979b). An essay on the past and future of information science education. II. Unresolved problems of 'extemalities' of education Information Processing \& Management, 15(4), 291-301.

[19] Vakkari, S.P. (1996). Library and information science: Content and scope. In J. Olaisen, E. Munch-Petersen, \& P. Wilson (Eds.), Information science: From development of the discipline to social interaction. Oslo, Norway: Scandinavian University Press.

[20] Vickery, B.C., \& Vickery, A. (1987). Information science in theory and practice. London: Butterworths.

[21] Wersig, G., \& Neveling, U. (1975). The phenomena of interest to information science. Information Scientist, 9, 127-140.

[22] White, H.D., \& McCain, K.W. (1997). Visualization of literatures. Annual Review of Information Science and Technology, 32, 99-168.

[23] www.en.wikipedia.org

[24] www.infosci.cornell.edu/

[25] www.ischools.org

[26] http://www.libsci.sc.edu/bob/istchron/iscnet/ischron.html 